Engineering History and Heritage Volume 168 Issue EH2

James Newlands and the origins of the municipal engineer

Sheard

ice | proceedings
Proceedings of the Institution of Civil Engineers Engineering History and Heritage 168 May 2015 Issue EH2 Pages 83-89 http://dx.doi.org/10.1680/ehah.14.00008 Paper 1400008

Received 10/04/2014

Published online 25/09/2015

Keywords: biography/history/municipal \& public service engineering

ICE Publishing: All rights reserved

\title{
James Newlands and the origins of the municipal engineer
}

Sally Sheard BA, PhD Hon, MFPH

Reader in History of Medicine, Department of Public Health and Policy,

University of Liverpool, Liverpool, UK

When James Newlands (1813-1871) arrived in Liverpool in 1847 to take up the newly created position of Borough Engineer, he formed, along with Dr William Henry Duncan (Medical Officer of Health) and Thomas Fresh (Inspector of Nuisances), Britain's first public health team. This was Liverpool's response to national and international perceptions of it as a dangerously unhealthy town. Frequent outbreaks of epidemic diseases and poor living conditions had created an 'urban penalty' - the price paid for its rapid uncontrolled expansion. Over the next 23 years, Newlands shaped this new role, defining its territory through Liverpool's ambitious programme of sanitary reform. He designed Britain's first purpose-built sewerage system and his holistic vision of sustainable urban living encompassed municipal baths and wash-houses, road planning, public parks and street lighting. Newlands' collaborations with other civil engineers, with Dr Duncan and Liverpool Town Council provide a fascinating and instructive case study on how expert advice is used in policy development. This paper illustrates how the relative professional status of medicine and engineering shaped the development of the discipline of public health. The challenges Newlands successfully addressed in mid-nineteenth century Liverpool - integrated urban design, adequate funding, multi-disciplinary team working - remain critical to urban health now.

\section{The nineteenth century urban penalty}

Liverpool in the early nineteenth century was a risky place to live. Home to a transient middle class, a merchant elite and to thousands of workers dependent on irregular dock work, it could bring great wealth or premature death. The town had grown rapidly - from a population of some 78000 in 1800 to nearly 250000 by 1841 . However, the urban administration remained firmly in the eighteenth century, with no powers to control housing quality or density, or urban design. This led to chronic insanitary conditions. Inadequate sewerage (intended for surface drainage only) resulted in frequent flooding of properties; refuse removal - scavenging - was done on demand. Privies and cesspits were left for months and sometimes years before being emptied and the streets were unpaved. In 1816 the eminent engineer John Rennie (1761-1821) had prepared a report for Liverpool Town Council for a system of intercepting sewers, but little progress was made.

By the 1830s the deterioration in urban health in many towns and cities was provoking national debate, within a predominant culture of laissez-faire - the Englishman's home is his castle principle (Sheard and Power, 2000). Edwin Chadwick (1800-1890) was appointed to lead the governmental enquiry into the sanitary state of the labouring population in 1842 . He had previously conducted the 1834 enquiry into the Poor Law, which had for the first time made an association between ill health and poverty, and instituted the construction of workhouses for the destitute.
One of Chadwick's main sources of information came from Dr William Henry Duncan (1805-1863), a Liverpool physician (Figure 2). He made regular inspections of some of the worst types of housing: courts, back-to-backs and cellars. Duncan had trained at Edinburgh before returning to Liverpool to set up a private practice, but he also volunteered his services at the fever hospital. He became convinced that the areas of overcrowding, closest to the docks, had the most ill health. In his evidence to the Royal Commission of 1842 he noted

I found the whole court inundated with fluid filth which had oozed through the walls from two adjoining ash-pits or cess-pools, and which had no means of escape in consequence of the court being below the level of the street and having no drain ... an intelligent Irishman who lived there told me that it was in vain to attempt to keep the court clean.... The stench at night he said was enough to "rise the roof off his skull as he lay in bed", and the court was never free from disease. (Duncan, 1842)

This insanitary state was reflected in Liverpool's mortality rates, which for the years 1839-1844 averaged 35 per thousand, while the national rate was around 25 per thousand. In years when epidemics of infectious diseases such as cholera and typhus struck the town, the rate could increase to over 45 per thousand, with even higher peaks among the poorest districts. Gerry Kearns has labelled this the 'urban penalty' - the price paid for insanitary urban living (Kearns, 1988) (Figure 3). 
James Newlands and the origins

of the municipal engineer

Sheard

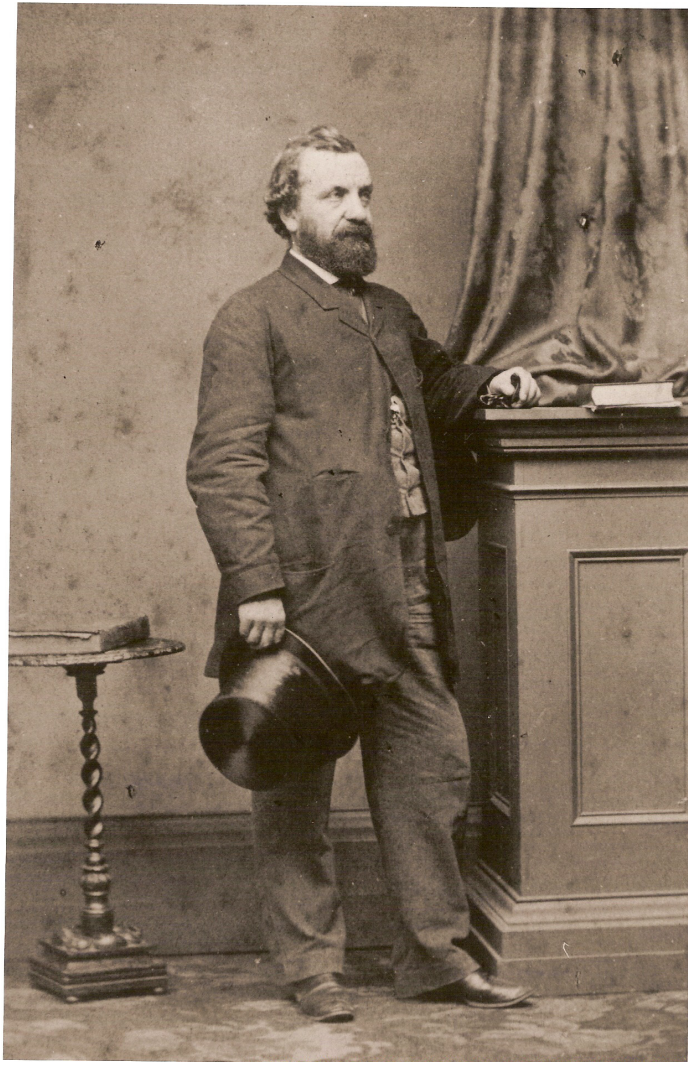

Figure 1. James Newlands (c. 1850s)

The increasing image of Liverpool as unhealthy, which was leading to ships being forced into quarantines in other ports, finally provoked the town council to take action through a local act of parliament in 1846. The resultant Liverpool Sanatory [sic] Act came into force on 1 January 1847. It established three key posts: the Medical Officer of Health (to which Duncan was appointed, initially part time), an Inspector of Nuisances (held by Thomas Fresh) and a Borough Engineer. This last post was in fact the most critical in driving Liverpool's sanitary reform, and the person appointed to it was James Newlands (Figure 1).

\section{James Newlands}

Newlands was born in Edinburgh on 28 July 1813, the son of a rope maker, and educated at Edinburgh University in mathematics and natural philosophy. He was then apprenticed to the Edinburgh architect Thomas Brown and became a skilled draughtsman. Between 1833 and 1836 he worked for the professor of agriculture David Low, designing farm buildings, and undertaking further studies in chemistry. He developed a private practice as an architect and a surveyor, valuing land bought up by railways. He was also an accomplished painter and flautist. In December 1846 Newlands replied to the

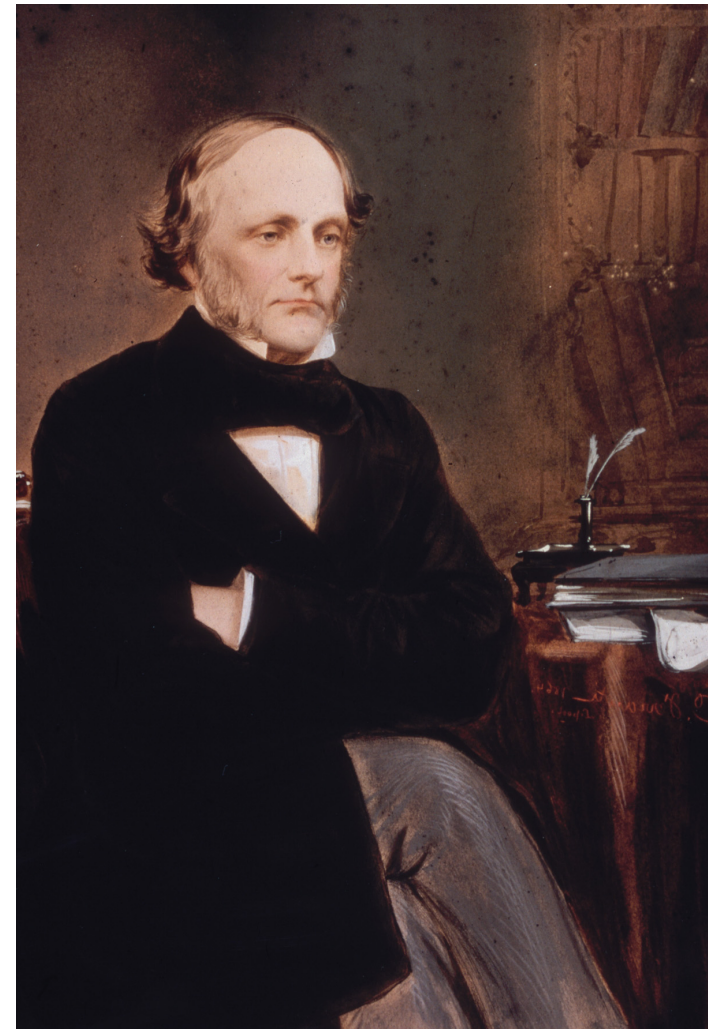

Figure 2. Dr William Henry Duncan (c. 1850s)

advertisement by Liverpool Town Council for 'A person duly qualified as a Civil Engineer, his duties to act as Local Surveyor of the Sewerage, Drainage, Paving and other works authorised by the Liverpool Sanatory Act, 1846' (Frazer, 1947). The 1854 Amendment Act required him to be called the Borough Engineer, a title that was used in practice from the outset.

Despite having very little experience in sewerage, drainage or street paving, he was selected from the five candidates, who included Chadwick's favoured engineer Robert Rawlinson (1810-1898), and began work in February 1847, aged 36, at a relatively high salary of $£ 700$ p.a. (Rawlinson later became chief of the local government board engineer inspectors in the 1870s and 1880s). Liverpool had previously employed John Foster senior (1758-1827), followed by John Foster junior (1787-1846) as town surveyors. However, the position was seen as relatively narrow in its remit, with no natural responsibility for sanitary reform, and Liverpool's surveyors had done virtually nothing to improve the drainage of the town, which flowed downhill towards the Mersey, but caused considerable flooding during wet weather.

Newlands' first investigation of the town highlighted this lack of sewerage, and he embarked on a detailed survey. This 
Engineering History and Heritage

Volume 168 Issue EH2
James Newlands and the origins of the municipal engineer

Sheard caused some complaints as the town had only recently been surveyed, but Newlands demanded much greater detail - at a scale of 1 inch to $20 \mathrm{ft}(2.5 \mathrm{~cm}$ to $6 \mathrm{~m})$. He also chose to employ private surveyors, not the Ordnance Survey or the army corps of engineers, to make more than 3000 geodetical observations. His vision, presented to the town council in his first report in April 1848, was for a system that went beyond removing surface water, and could be linked to water closets (WCs) through house drains, to replace the traditional cesspits and privies (Figure 3). The water-suspended sewage would then be transported out of the town to the surrounding agricultural land to use as fertilizer, as favoured by Chadwick in his holistic urban system. A water-based sewerage system was now feasible in Liverpool after the town council had municipalised the two private water companies and looked to introduce a constant water supply by constructing a reservoir at Rivington in north Lancashire.

The expansiveness of Newlands' first report makes it one of the most prescient documents of this pioneering public health age. As Chris Hamlin notes, 'Newlands, like Chadwick, understood that physical, social and cultural causes and consequences of disease were interconnected. He was concerned with everything - from the minimum cubic footage of rooms in dwelling houses to the provision of swimming lessons. Such a transformation required one plan for the development of the town, linked to a coherent set of technical principles' (Hamlin, 1994). Newlands openly criticised the schemes of Foster and Rennie for putting intercepting sewers at too high a level to be useful, and for not having the foresight to plan for the expansion of the town. He suggested that he should also have authority to determine the layout of new streets to minimise drainage costs and that he should have jurisdiction over the administratively separate outlying districts of Everton, Kirkdale and Toxteth Park, as he envisaged they would soon form part of a continuous urban environment.

The 1848 report provided prototypes for such widely divergent items as lamp posts with integral water hydrants and that also displayed street names and distances from the town hall to help cabbies correctly calculate their fares (Figure 4). Newlands further developed plans for the regulation of slaughterhouses, regular refuse collection, the construction of public baths, washhouses and public urinals - the latter, of course, for men only

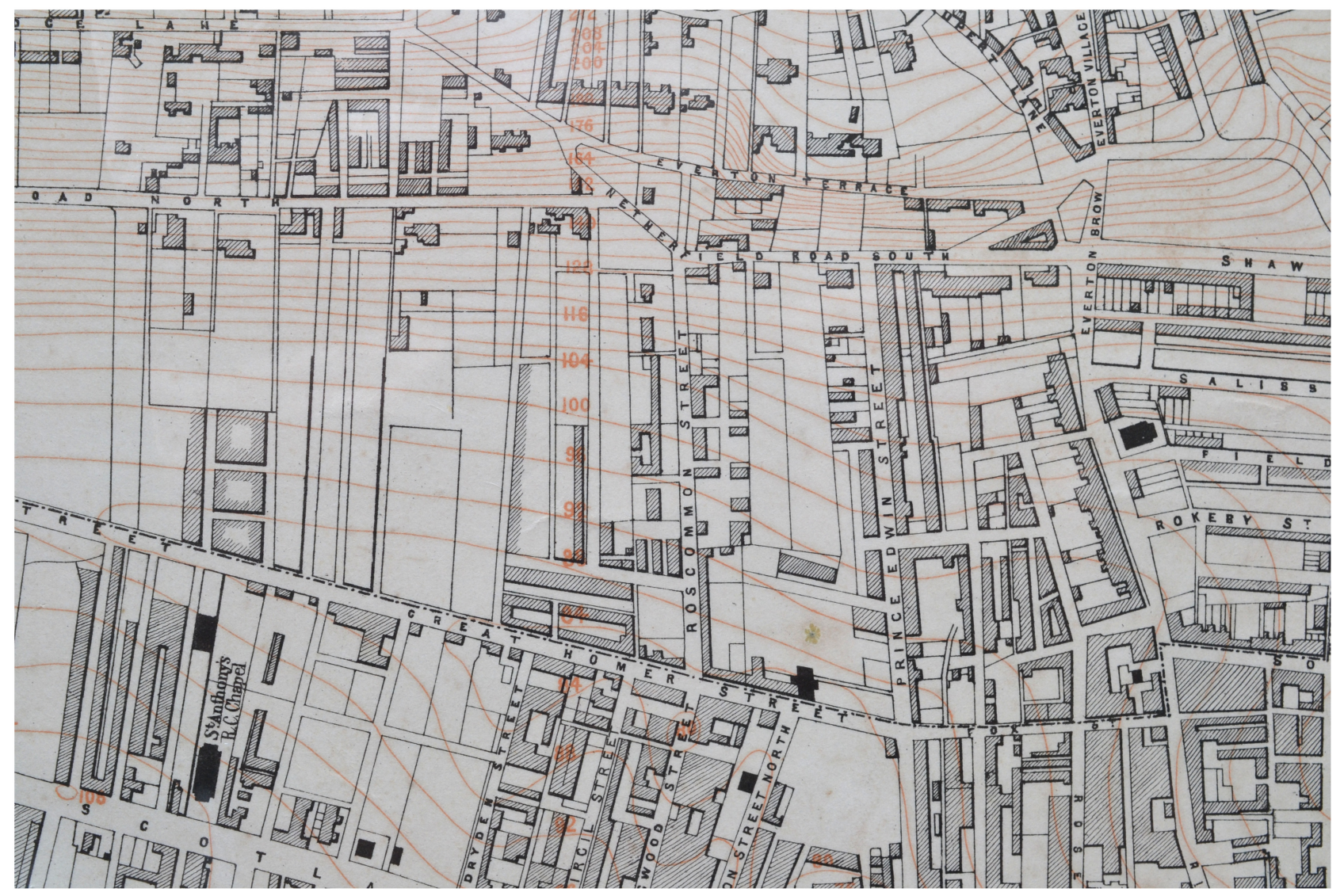

Figure 3. A section from Newlands' 1848 survey of Liverpool 


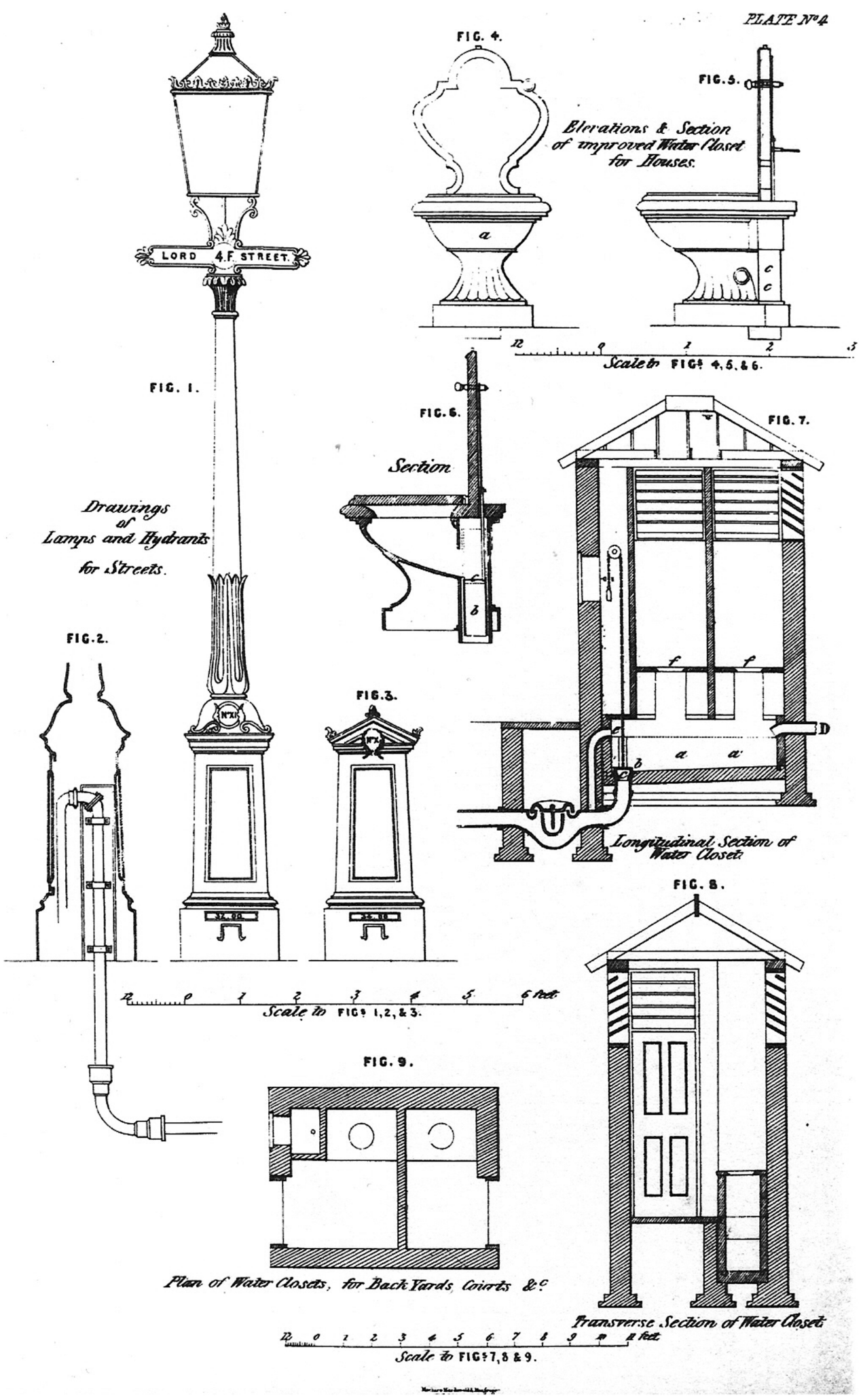

Figure 4. Newlands' designs for urban furniture and water closets 
Engineering History and Heritage

Volume 168 Issue EH2
James Newlands and the origins of the municipal engineer Sheard
(Sheard, 2000). All these were imbued with his principles of sanitary living to improve health - based on access to light and air - that reflected the current miasmatic understanding of disease transmission, which held that most disease was caused by bad smells emanating from rotting matter (such as sewage). This theory was not replaced until the slow emergence of germ theory from the 1860s. Like Chadwick, Newlands believed that physical surroundings also affected mental outlook and moral wellbeing. It is worth quoting his 1848 report at length in which his views on bathrooms illuminate his attention to the minutiae of sanitary reform (Figure 6).

In the private baths [in proposed municipal baths], each apartment should be sufficiently large to admit of the bath standing in the middle of the room, with a clear space all round. To those persons in whom the habit of bathing has to be induced, the going down into a dark dirty looking hole, thrust into a corner, is not very likely to tempt them to renew the experiment.... The apartment should be as light as possible - light is the best handmaid of all cleanliness. The walls and ceiling should be smoothly plastered, the latter arched if possible.... The dressing door handles, and the like articles, should be of white stone ware. The difference between the highest and lowest classes fittings should only be in quality. There should be the same comforts in each.

Newlands' designs for communal kitchens and bathing were in essence a form of social engineering, based on collective responsibility and personal morality. His report was an audacious cross of an engineering study and a socialist manifesto. As Hamlin has noted, municipal engineers in other towns did not produce similar reports, and usually found it prudent to keep to a strictly technical line and avoid politics and ideology (Hamlin, 1994). Significantly, it is only this first report of 1848 that contains Newlands' wider views - his later

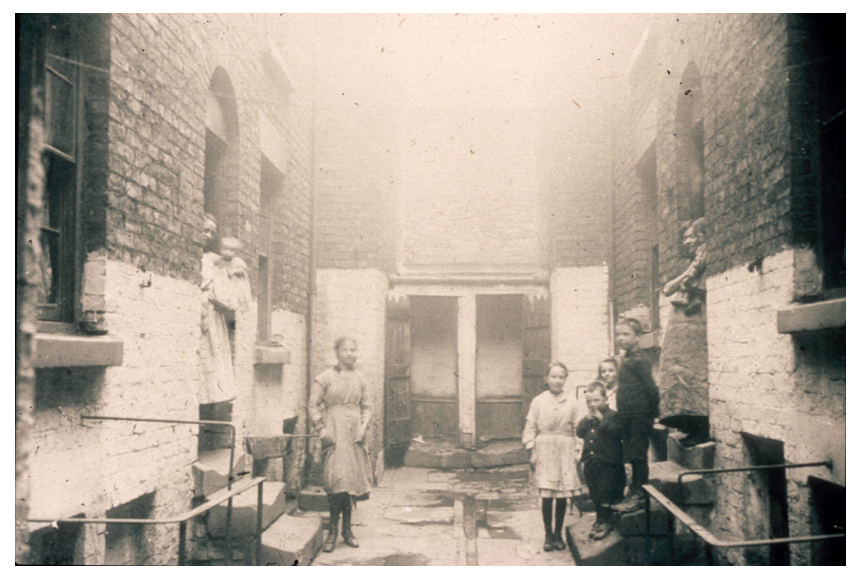

Figure 5. Insanitary housing conditions in late nineteenth-century Liverpool

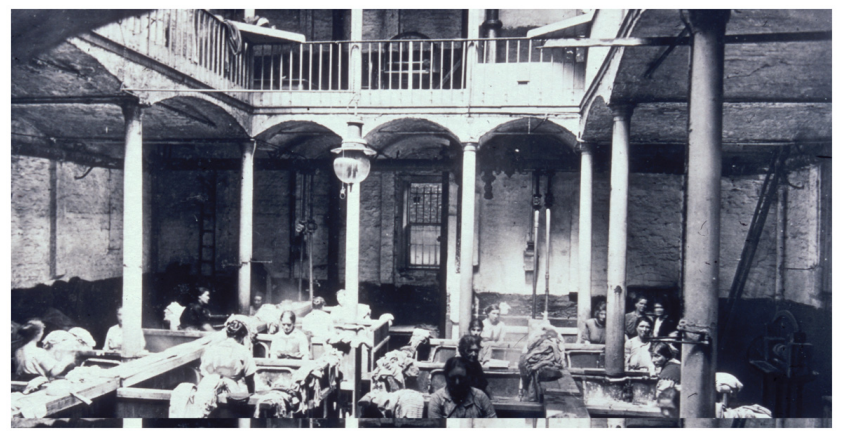

Figure 6. A late nineteenth-century Liverpool municipal wash house

ones were much briefer and written in a more conventional public servant style. Sadly his proposal for a ring road of boulevards and urban parks was not adopted during his lifetime, but was later constructed by John Alexander Brodie (1858-1934). Newlands developed his role to embrace both civil engineering and town planning, long before the latter was recognised as a profession in its own right.

\section{Britain's first integrated sewerage system}

Construction of Newlands' sewer system began in 1848. As the first such scheme in Britain its progress was closely watched by the national public health and civil engineering communities, and pre-dates Joseph Bazalgette's scheme for London, which was started after the 'great stink' of 1858. By the time of Newlands' 1851 report some 17 miles $(27 \mathrm{~km})$ had been constructed, mainly of $3 \mathrm{ft} \times 1 \mathrm{ft} 10$ ins $(91.4 \mathrm{~cm} \times 55.9 \mathrm{~cm})$ ovoids. His sewer pipes were designed for manufacture with eyes for easy house drain connections (amid the heated battle of the pipe and brick sewer war between Chadwick and the engineering community, which continued to favour square brick-built sewers). Trapped gullies were introduced, but this exacerbated the problem of the build-up of sewer gasses. Newlands wanted to link the sewers to a redundant chimney to burn them off, but was refused council permission. He designed flushing valves, and promoted street planning with rear passageways behind houses to give access to drains, and for household refuse collection.

Newlands' 1848 system had been largely completed by 1869 , stretching to nearly 300 miles $(483 \mathrm{~km})$ of sewers and drains. This was a significant achievement, but its success and that of the related WC conversion programme caused problems because Liverpool did not yet have its promised constant water supply. Droughts and miscalculations on the Rivington scheme designed by Thomas Hawksley (1807-1893) left the town dangerously short of water, which meant some sewers needed manually digging out, and new connections to WCs were 
forbidden. Because of the cost of the proposed land irrigation element of the scheme, the River Mersey was chosen instead as the location for the sewer outfalls, which discharged untreated sewage until the construction of the Mersey estuary pollution alleviation scheme in the 1990s.

\section{Wider social and sanitary concerns}

Some of the sanitary reforms that Liverpool carried out under direction from Duncan and Newlands would now appear myopic, indeed brutal, when coinciding with the construction of magnificent and expensive civic buildings such as St Georges Hall. The overcrowding problem had been made worse by the arrival of around 300000 destitute Irish fleeing the 1846 potato famine. The numbers of people living in cellars rose to 45000 . The council's response to this overcrowding was to issue bye-laws, and to demolish insanitary property (Figure 5). It was not until 1868 that Newlands finally got his desired pilot public housing scheme - but this was a small, ineffective, panacea for only some of the 25000 people who were made homeless during the slum clearances of the 1850s.

Newlands' sanitary reform policies gained him national and international attention. In 1855 he was given leave from Liverpool to go to the Crimea as a government sanitary commissioner to direct the cleaning up of the disastrous conditions in the army camps at Sebastopol after the battle of Balaclava. Florence Nightingale sent a letter of appreciation to Liverpool council on Newlands' work: 'Truly I may say that to us sanitary salvation came from Liverpool.'

Newlands' endeavours were also recognised by the Institution of Civil Engineers (ICE), which had been founded in 1818 (Watson, 1988). He was elected an associate in 1848, and to the class of members in 1857 (Jarvis and Ruddock, 2008). When he was in London he regularly attended institution meetings and engaged in its debates. His title of Borough Engineer was adopted by many towns and cities through the permissive 1848 Public Health Act, which was closely modelled on the 1846 Liverpool Sanatory Act. Newlands' career in Liverpool did much to define municipal engineering and to shape the emerging profession. He demonstrated that to be effective it was necessary sometimes to let the councillors believe that the ideas had been theirs, and to tread a fine line between municipal servant and independent policy expert. His relationship with Liverpool's first Medical Officer of Health, Dr Duncan, was also critical to the development of an effective public health policy for Liverpool. They routinely collaborated, agreeing which areas of the town had the worst health problems that were amenable to engineering interventions such as sewers, clean water and street paving.

Newlands suffered throughout his life from chronic bronchitis, made worse by his punishing workload. His wife died childless
3 years after their marriage, and his home was subsequently managed by his sister. He formally retired in June 1871 to move to a consulting role, but died 6 weeks later at the age of 58 on 15 July (ICE, 1871-1872). Although he had deliberately cultivated a 'backroom' type of role in Liverpool, his reputation was such that the public lined the streets for the funeral procession, which was attended by national figures from the world of civil engineering. By the early 1870s Liverpool's mortality rate had significantly improved, and outbreaks of infectious diseases such as cholera, typhus and typhoid were much less severe. After Newlands' death the council commissioned a marble bust, and in 1997 as part of the 150th anniversary of Liverpool's pioneering public health policy, plaques were unveiled on two of his homes.

\section{Doctors versus engineers}

The relationship between Newlands and Duncan provides a useful case study of nineteenth-century urban reform. It illuminates the importance of personality in effective policy formation, and the limitations imposed by public and state perceptions of the medical and engineering professions (Sheard and Donaldson, 2005). In Liverpool Newlands was seen as professionally and socially inferior to Duncan. This was reflected in his salary, style of clothes, friendship networks and the attitude of the town council. This relative status of Medical Officer of Health and Borough - later Municipal - Engineer was replicated in towns and cities throughout Britain, at a formative time in the establishment of public health systems. Nationally, too, it took some time for the profession of civil engineering to reach the level of expert authority already held by medicine. ICE consciously emulated the architecture and customs of the Royal Colleges of Physicians and Surgeons, and cultivated connections with senior civil servants and politicians.

The municipal engineer after Newlands' era has been integral to the health of the population, and an Association of Municipal Engineers was formed in 1874, the year before the great Public Health Act (and merged with ICE in 1984). A journal was also established, and in 1883 Henry Boulnois published the first Municipal and Sanitary Engineer's Handbook (Boulnois, 1883). Yet the medical profession has been slow to acknowledge the role of engineering in public health. Text books authored by medical officers of health from the early twentieth century have large sections on water supply, slum clearance, parks, waste management and so on, but there is no discussion of the personnel or professional skills of those responsible for these systems (Fraser, 1948; Hope, 1931). The work of engineers even provided the derogatory slang used by 'proper doctors' for their municipally employed medical officer of health colleagues - they were 'drains doctors'.

The restructuring of the NHS, and medical public health, especially in 1974, which abolished local government departments 
of public health and re-branded medical officers of health as community physicians, provided a new opportunity for integrated public health. Liverpool was again at the forefront of change - pioneering a joint public health team with representatives of the NHS and local authorities in the 1980s and consciously bringing municipal engineering back into the relationship alongside environmental health.

James Newlands is a fascinating character. His work demonstrates what can be achieved under the duress of financial stringency, ratepayer and government opposition to public investment, and traditional subservience to fellow professionals. He was a politician, skilful in steering the best possible course, and always making evidence-based policy recommendations. The engineering profession can still learn a lot from him.

\section{REFERENCES}

Boulnois HP (1883) The Municipal and Sanitary Engineer's Handbook. Spon, London, UK.

Duncan WH (1842) Report on the Sanitary State of Liverpool,

Evidence to the Inquiry into the Sanitary Condition of the

Labouring Population. Parliamentary papers HL XXVII,

London, UK, p. 282.

Frazer WM (1947) Duncan of Liverpool. Hamish Hamilton, Liverpool, UK.

Frazer WM (1948) A Textbook of Public Health. Livingstone, Edinburgh, UK.
Hamlin C (1994) James Newlands and the bounds of public health. Transactions of the Historic Society of Lancashire and Cheshire 143: 117-139.

Hope EW (1931) Health at the Gateway: Problems and International Obligations of a Seaport City. Cambridge University Press, Cambridge, UK.

ICE (Institution of Civil Engineers) (1871-1872) Minutes of Proceedings 33: 227-231.

Jarvis A and Ruddock T (2008) James Newlands. In Biographical Dictionary of Civil Engineers in Great Britain and Ireland Volume 2 1830-1890 (Cross-Rudkin PSM, Chrimes MM, Bailey MR et al. (eds)). Thomas Telford, London, UK.

Kearns G (1988) The urban penalty and the population history of England. In Society, Health and Population during the Demographic Transition. (Brandstrom A and Tedebrand L-G (eds)). Almqvist and Wiksell International, Stockholm, Sweden, pp. 213-238.

Sheard S (2000) Profit is a dirty word: the development of public baths and wash-houses in Britain 1847-1915. Social History of Medicine 13(1): 63-85.

Sheard S and Donaldson L (2005) The Nation's Doctor: the Role of the Chief Medical Officer, 1855-1998. Radcliffe, Oxford, UK.

Sheard S and Power H (2000) Body and City: Histories of Urban Public Health. Ashgate, Aldershot, UK.

Watson G (1988) The Civils: The Story of the Institution of Civil Engineers. Thomas Telford, London, UK.

\section{WHAT DO YOU THINK?}

To discuss this paper, please email up to 500 words to the editor at journals@ice.org.uk. Your contribution will be forwarded to the author(s) for a reply and, if considered appropriate by the editorial panel, will be published as discussion in a future issue of the journal.

Proceedings journals rely entirely on contributions sent in by civil engineering professionals, academics and students. Papers should be 2000-5000 words long (briefing papers should be 1000-2000 words long), with adequate illustrations and references. You can submit your paper online via www.icevirtuallibrary.com/content/journals, where you will also find detailed author guidelines. 